\title{
Geological programmes come under threat ...
}

Washington. Earth scientists in the United States are growing increasingly concerned that the US Geological Survey (USGS) the largest source of federal funding for US hydrologists, geologists and geophysicists - may be abolished in the new year unless they can persuade Congress that its $\$ 600$ million annual costs provide taxpayers with value for money.

The Republican threat to abolish the agency arose in a drastic budget-cutting amendment in 1993. It reappeared in a minority budget proposal in March, and was then attached to the Contract with America, the platform on which the party won November's elections.

The survey is best known for mapping and geology, including assessing the risks from earthquakes and volcanoes, but its largest function is based on its responsibility to collect and assess hydrological data to help manage the US water supply.

\section{. . . as Walker picks out new targets}

Washington. The new Republican chairman of the House of Representatives Science Committee says that he plans to look closely at large-scale environmental research programmes, such as the National Aeronautics and Space Administration's (NASA)'s Mission to Planet Earth and other projects related to global warming, which he claims may be "more in tune with political priorities" than with good science.

Bob Walker (Republican, Pennsylvania) has also promised to encourage the National Science Foundation (NSF) to put greater emphasis on basic science, and to pursue legislation to enhance the role of risk assessment in environmental legislation.

Addressing a meeting of journalists and lobbyists in Washington last week, Walker was broadly supportive of existing government-backed research programmes, and short on proposals for drastic budget cuts.

But he said that the Clinton administration's fastest-growing research programme, the Advanced Technology Program, run by the National Institute of Standards and Technology, should "ultimately" be phased out. $\mathrm{He}$ also expressed concern that the costs of the proposed Tokamak Physics Experiment at the Princeton Plasma Physics Laboratory in New Jersey "have gone up 50 per cent", and suggested that fusion experiments were best carried out internationally.

Walker has successfully fended off plans to rename his committee, formerly the Science, Space and Technology Committee, chaired by George Brown (Democrat, California), as the Technology and Competitiveness Committee. Instead, it will be known simply as the Science Committee.

Walker's close ties with the Republican leaders in the House, and his close personal friendship with the speaker Newt Gingrich (Republican, Georgia), in particular, should strengthen his committee's influence and help to improve its poor legislative track record.

In addition, changes in committee structure in the Senate, giving a greater voice to authorization committees, will make it easier than before to reach agreement on authorizing legislation. Even Brown concedes this point. "Previously the Senate had shafted us," he says. "We now have people on both sides who want authorizing bills, and we will get them."

Walker pledged to continue Brown's campaign against congressional earmarking of funds for academic projects, and to hold early hearings at which agency chiefs such as Dan Goldin, the administrator of NASA, will be asked to describe their visions for the next century. He also said that the NSF, which has recently been under

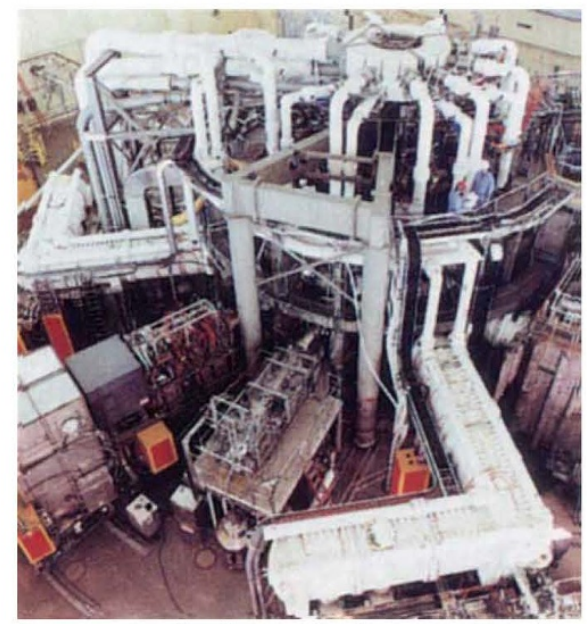

Concerns raised over the increased costs of fusion research at Princeton (above).

pressure from a Democratic Congress to boost its education and applied research programmes, should be "far more concentrated on basic science".

But Walker's first priority is likely to be to promote legislation in the arcane but important sphere of risk assessment. He believes that new legislation is needed to devise a framework for the federal government's response to perceived environmental threats such as global warming, deforestation and endangered species.

Such legislation, although highly technical, will be extremely contentious It will attempt to lay a basis for action in such fields in terms of demonstrated cost-effectiveness, based on proven science, rather than on political commitment.
The few congressmen who have so far voiced objections to the proposed abolition are Californians concerned about the future of the survey's work on the likelihood and impact of earthquakes, said a spokesman for John Kasich (Republican, Ohio), the chairman of the House of Representatives Budget Committee. It was committee staff members who put the survey on the hit-list.

But the spokesman emphasized that the list was intended only to exemplify what sorts of budget cuts could be made. "We did not say 'you have to use these cuts'," he said. "If people have other suggestions, we are ready to hear them."

The American Geological Institute (AGI), which represents 80,000 Earth scientists, is planning a campaign to defend the survey, as is the American Geophysical Union. Craig Schiffries, government affairs director at AGI, warns geologists to be aware of the dangers of "a pyrrhic victory, where [the Republicans] don't abolish the agency but cut its budget by 30 per cent".

Gordon Eaton, director of the survey, says that its failure to explain its functions adequately to the public is part of the present problem. "All of them relate to public health, safety, and the economic well-being of the nation."

Eaton has won assurances from his boss, Bruce Babbitt, the Secretary of the Interior, that the agency has the full support of the administration. But the threat to the agency is partly motivated by Republican loathing of Babbitt - the official in the administration most closely associated with environmentalist thinking - - and he may not be well positioned to provide protection.

Two other science agencies in Babbitt's department, the National Biological Survey (NBS) and the Bureau of Mines, are also threatened with closure. The USGS will spend \$362 million on research and development this year, the NBS \$167 million, and the Bureau of Mines \$101 million. Most observers feel that the two smaller agencies are more vulnerable than the USGS.

As a heavily staffed federal agency with offices and collaborations in every state in the union, the survey may seem the typical sort of agency that Republicans would like to close. But unlike many federal agencies, it has a strong record of performing highquality intramural research.

The survey has established centres of research excellence in the Earth sciences whose publication rates are as high as university centres, says George Brown (Democrat, California), now ranking minority member of the House of Representatives Science Committee. "That's the sort of thing we ought to be encouraging," he says adding that he does not believe that there is "a chance in a million" that USGS will actually be abolished. Colin Macilwain 